University of Nebraska - Lincoln

DigitalCommons@University of Nebraska - Lincoln

Publications from USDA-ARS / UNL Faculty

U.S. Department of Agriculture: Agricultural

Research Service, Lincoln, Nebraska

November 1978

\title{
Growth Analysis of Tall Fescue Genotypes Differing in Yield and Leaf Photosynthesis
}

Wallace Wilhelm

University of Nebraska-Lincoln, wwilhelm1@unl.edu

C. J. Nelson

USDA

Follow this and additional works at: https://digitalcommons.unl.edu/usdaarsfacpub

Part of the Agricultural Science Commons

Wilhelm, Wallace and Nelson, C. J., "Growth Analysis of Tall Fescue Genotypes Differing in Yield and Leaf Photosynthesis" (1978). Publications from USDA-ARS / UNL Faculty. 124.

https://digitalcommons.unl.edu/usdaarsfacpub/124

This Article is brought to you for free and open access by the U.S. Department of Agriculture: Agricultural Research Service, Lincoln, Nebraska at DigitalCommons@University of Nebraska - Lincoln. It has been accepted for inclusion in Publications from USDA-ARS / UNL Faculty by an authorized administrator of DigitalCommons@University of Nebraska - Lincoln. 


\title{
Growth Analysis of Tall Fescue Genotypes Differing in Yield and Leaf Photosynthesis ${ }^{1}$
}

\author{
W. W. Wilhelm and C. J. Nelson ${ }^{2}$
}

\begin{abstract}
Relationships between leaf photosynthesis and yield have not been well defined in forage grasses. Therefore, leaf growth, dry matter distribution, carbohydrate concentration, and growth analysis of four genotypes of tall fescue (Festuca arundinacea Schreb.) were examined. Genotypes, selected in the field for high and low $\mathrm{CO}_{2}$ exchange rate (CER) in combination with high and low yield, were compared in an attempt to study the relationship between photosynthesis and yield.

In the vegetative growth stage, high yielding genotypes produced greater amounts of all plant parts (leaves, stem bases, and roots) than did low yielding genotypes; how. ever, low yielding genotypes produced more leaf tissue relative to total increase in plant dry weight than did high yielding genotypes. Water-soluble carbohydrate (WSC) concentrations of plant parts were significantly different among genotypes, with high-CER genotypes having highest levels during early stages of regrowth. High yielding genotypes had highest WSC concentrations at later stages regardless of CER rating.

Mean relative growth rates of the four genotypes were similar. Mean net assimilation rates and mean relative leaf area growth rates tended to be greater for the high yielding genotypes than for the low yielding genotypes. Results indicated the greater yields exhibited by the high yielding genotypes regardless of CER rating resulted from (1) greater carbohydrate reserves to initiate new leaf growth, (2) more rapid leaf area development, and (3) partitioning a greater amount of newly assimilated dry matter into leaf tissue during the first 16 to 19 days of regrowth.
\end{abstract}

Additional index words: Festuca arundinacea Schreb., Relative growth rate, Net assimilation rate, Dry matter distribution, Water-soluble carbohydrates, Regrowth, Leaf area development, Harvest index.

D IFFERENTIAL dry matter distribution (Yoshida, 1972; Treharne and Eagles, 1970), leaf growth rate (Hanson, 1971; Yoshida, 1972; Hoveland et al., 1974), and carbohydrate storage (Treharne and Eagles, 1970) have been suggested as plant characteristics which may influence the relationship between $\mathrm{CO}_{2}$ exchange rate (CER) and yield in crop species. Nelson and Asay (1974) and Nelson et al. (1975) have reported an inconsistent relationship between leaf CER

\footnotetext{
${ }^{1}$ Contribution from the Missouri Agric. Exp. Stn. Journal Series 8011. Received 23 Feb. 1978.

${ }^{2}$ Graduate assistant (now plant physiologist, SEA, USDA, Lincoln NE 68583) and professor of agronomy, Dep. of Agronomy, Univ. of Missouri-Columbia, Columbia MO 65201 .

a Mention of a trademark or proprietary product does not constitute a guarantee or warranty of the product by the USDA or the Missouri Agric. Exp. Stn. and does not imply their ap. proval to the exclusion of other products that may be suitable.
}

and forage yield of tall fescue (Festuca arundinacea Schreb.). Further, they suggested that the aforementioned phenomena may be limiting the genetic expression of leaf CER in terms of forage yield.

In earlier studies (Wilhelm and Nelson, 1978a,b), it was reported that genotypic interaction with photosynthetic photon flux density (PPFD), leaf age, and time of day did not significantly influence the leaf CER-yield relationship of tall fescue. The present study was conducted to determine if genotypes of tall fescue selected for different CER and yield levels differed in dry matter distribution, leaf growth rate, and carbohydrate concentrations in various plant parts.

\section{MATERIALS AND METHODS}

Four genotypes of tall fescue were selected to represent each of four categories: high CER-high yield (H-H), high CERlow yield (H-L), low CER-high yield (L-H), and low CER-low yield (L-L). Genotypes used in this study were originally selected for early flowering. Yield and CER of these genotypes were originally determined in field studies during 1972 and 1973 (Nelson et al., 1975) and are described by Wilhelm and Nelson (1978a). In general, the high category genotypes had about $30 \%$ greater CER and $32 \%$ greater yield than did the low category genotypes.

Three regetative tillers of each genotype were planted in each of eight pots constructed of $38-\mathrm{cm}$ lengths of $10 \mathrm{~cm}$ diameter plastic drain pipe with pegboard bottoms to allow adequate drainage. Soil mixture was composed of equal parts of sand and Mexico silt loam topsoil. Plants were allowed to become established for approximately 2 months in a greenhouse with natural day lengths and temperatures between 15 and 30 C. After establishment plants were moved into a controlled environment chamber with a 14-hour photoperiod $\left(500 \mu \mathrm{E} \mathrm{m}^{-2}\right.$ $\mathrm{sec}^{-1}, 400$ to $700 \mathrm{~nm}$ ), $20 / 15 \mathrm{C}$ (light/dark) temperature, and greater than $50 \%$ relative humidity. At that time, tiller number per pot averaged $43,32,48$, and 38 for the H-H, H-L, L-H, and L-L genotypes, respectively. Plants were watered daily. Once each week, $50 \mathrm{ml}$ of complete nutrient solution (Epstein, 1972) was added.

After a 2-week acclimatization period in the growth chamber, paired plants were allotted into four replications according to tiller number and herbage was cut to leave a $6-\mathrm{cm}$ stubble and discarded. Plants were allowed to regrow. One of the two pots per replication of each genotype was harvested 4 days after the herbage had been removed (initial harvest). This avoided the lag phase during initial regrowth (Booysen and Nelson, 1975), and growth analyses were calculated when dryweight accumulation was nearly linear. Remaining plants were allowed to regrow for 19 additional days before they were harvested (final harvest). The experiment was repeated with the same genotypes and conditions except that the regrowth period between harvests was 16 days. Similar results occurred, so data were combined for analysis and presentation.

At each harvest (initial and final), roots were washed free of soil and plants separated into leaf tissue $6 \mathrm{~cm}$ above soil, stem bases plus leaf sheath below $6 \mathrm{~cm}$, and roots. Leaf blade area 
Table 1. Water-soluble carbohydrate (WSC) concentration in plant components of four tall fescue genotypes at initial and final harvests. Genotypes of tall fescue selected for high (H) and low (L) $\mathrm{CO}_{2}$ exchange rate (CER) and yield.

\begin{tabular}{lccr}
\hline Component & Genotype & Initial & Final \\
\hline \multirow{3}{*}{ Leaves } & (CER-yield) & - WSC, \% & \\
\cline { 2 - 4 } & H-H & 9.0 & 21.1 \\
& H-L & 8.1 & 14.5 \\
L-H & 5.0 & 20.8 \\
L.S.D. (0.05) & L-L & 4.6 & 12.5 \\
Stem bases & & 3.2 & 2.3 \\
& H-H & 28.5 & 28.2 \\
& H-L & 29.7 & 26.5 \\
L.S.D. (0.05) & L-H & 13.1 & 17.6 \\
Loots & L-L & 14.0 & 21.1 \\
& & 5.4 & 2.5 \\
& H-H & 4.0 & 4.8 \\
& H-L & 2.6 & 3.6 \\
L.S.D. (0.05) & L-H & 1.3 & 2.3 \\
& L-L & 1.8 & 3.0 \\
& & 0.6 & 0.7 \\
\hline
\end{tabular}

was determined with a Lambda Instruments LI-300 $0^{3}$ leaf area

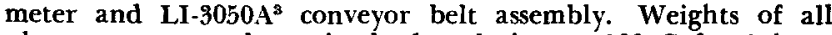
plant parts were determined after drying at $100 \mathrm{C}$ for 1 hour and $70 \mathrm{C}$ for 48 hours. Carbohydrates were extracted from ground (40-mesh screen) tissue with distilled water (25 C). After acid hydrolysis of the extract, percent water-soluble carbohydrates (WSC) was measured by the copper reduction and iodine titration method using fructose as a standard (Smith, 1969).

Mean net assimilation rate $\overline{(\mathrm{NAR})}$, mean relative growth rate $\overline{(\mathrm{RGR})}$, mean leaf area ratio $\overline{(\mathrm{LAR})}$, and mean relative leaf area growth rate $\overline{(\mathrm{RLaGR})}$ were calculated (Radford, 1967) using combined top and root weight data and the following equations:

$$
\begin{aligned}
& \overline{\text { NAR }}=\frac{\left(W_{2}-W_{1}\right)}{\left(A_{2}-A_{1}\right)} \cdot \frac{\left(\ln A_{2}-\ln A_{1}\right)}{\left(t_{2}-t_{1}\right)} ; \\
& \overline{\text { RGR }}=\frac{\left(\ln W_{2}-\ln W_{1}\right)}{\left(t_{2}-t_{1}\right)} ; \\
& \overline{\mathbf{L A R}}=\frac{\left(A_{2}-A_{1}\right)}{\left(W_{2}-W_{1}\right)} \cdot \frac{\left(\ln W_{2}-\ln W_{1}\right)}{\left(\ln A_{2}-\ln A_{1}\right)} ; \\
& \overline{\text { RLaGR }}=\frac{\left(\ln A_{2}-\ln A_{1}\right)}{\left(t_{2}-t_{1}\right)} ;
\end{aligned}
$$

where

$$
\begin{aligned}
& A_{1}=\text { initial leaf area }\left(\mathrm{dm}^{2}\right) ; \\
& A_{2}=\text { final leaf area }\left(\mathrm{dm}^{2}\right) ; \\
& \mathbf{W}_{1}=\text { initial plant weight }(\mathrm{g}) ; \\
& \mathbf{W}_{2}=\text { final plant weight }(\mathrm{g}) ; \\
& \mathbf{t}_{1}=\text { initial time (days); } \\
& \mathbf{t}_{2}=\text { final time (days). }
\end{aligned}
$$

Carbon dioxide exchange rate was measured on newly collared leaves approximately 14 days after the initial harvest using infrared gas analysis and air-sealed chambers as described by Nelson et al. (1974). The system was modified so two leaves per experimental unit were measured simultaneously.

\section{RESULTS AND DISCUSSION}

All genotypes had a greater percentage of the leaf dry matter in the form of WSC at the final harvest than at the initial harvest. However the two highCER genotypes showed a trend toward higher WSC percent in leaf tissue initially, while the two high yielding genotypes had higher WSC percent at the final harvest (Table 1). In contrast, WSC concentra-
Table 2. Plant component weights and change during regrowth for genotypes of tall fescue selected for high (H) and low (L) $\mathrm{CO}_{2}$ exchange rate (CER) and yield.

\begin{tabular}{lcrrr}
\hline Component & Genotype & Initial & Final & Change \\
\hline & (CER-yield) & & g & \\
\cline { 2 - 4 } Leaves & H-H & 0.84 & 3.71 & 2.87 \\
& H-L & 1.06 & 2.51 & 1.45 \\
& L-H & 0.98 & 3.86 & 2.87 \\
L.S.D. (0.05) & L-L & 0.96 & 2.43 & 1.48 \\
Stem bases & & NS & 0.62 & 0.76 \\
& H-H & 4.92 & 7.49 & 2.57 \\
& H-L & 3.24 & 4.87 & 1.64 \\
L.S.D. (0.05) & L-H & 3.99 & 5.47 & 1.48 \\
Roots & L-L & 3.10 & 4.11 & 1.01 \\
& & 0.94 & 0.91 & 1.26 \\
& H-H & 6.17 & 8.06 & 1.89 \\
& H-L & 2.87 & 4.52 & 1.65 \\
L.S.D. (0.05) & L-H & 7.30 & 8.93 & 1.63 \\
Total & L-L & 2.60 & 2.97 & 0.37 \\
& & 1.66 & 1.42 & NS \\
& H-H & 11.93 & 19.26 & 7.33 \\
& H-L & 7.16 & 11.90 & 4.74 \\
L.S.D. (0.05) & L-H & 12.27 & 18.26 & 5.99 \\
& & 6.66 & 9.51 & 2.85 \\
& & 2.43 & 2.83 & 3.94 \\
\hline
\end{tabular}

tion of stem bases was more closely associated with GER at both harvest dates. Concentration of WSC in roots was less than that in leaves and stem bases, and tended to be higher in high-CER genotypes than in low-CER genotypes. This suggested that, although CER may not be directly related to yield (Nelson and Asay, 1974; Nelson et al., 1975), there appeared to be a WSC advantage during early stages of growth in genotypes with high leaf CER. However, later in regrowth, the additional growth advantage of rapid leaf area development (Wilhelm and Nelson, 1978b) apparently led to higher WSC levels in high yielding genotypes.

High yielding genotypes, regardless of CER, exhibited greater increases in leaf dry weight between harvest than did the low yielding genotypes (Table 2). Comparison within each CER category at the final harvest showed that high yielding genotypes had produced more stem base and root tissue than low yield. ing genotypes. When whole-plant data were considered, high yielding genotypes tended to have greater dry matter increases.

Initial leaf areas were similar for all genotypes, except $\mathrm{H}-\mathrm{H}$, which was significantly lower than the H-L and L-H genotypes (Table 3). At the final harvest the high yielding genotypes had a greater leaf area than did the low yielding genotypes. The increase in leaf area between the two harvests was also significantly greater for the high yielding genotypes than the low yielding genotypes. This is consistent with the leaf weight data presented in Table 2 and also sug. gests similarity in specific leaf weights (SLW) among the four genotypes, which were 5.8, 5.4, 5.7, and 5.7 $\mathrm{mg} / \mathrm{cm}^{2}$ for the H-H, H-L, L-H, and L-L genotypes, respectively.

The ratio of weight of leaf tissue to weight of stem base plus root tissues (Table 3) gives an indication of the proportion of economic to noneconomic yield [harvest index $=$ leaf weight/ (stem base weight + 
Table 3. Initial, final, and change in leaf area, harvest index, and tiller number for tall fescue genotypes during regrowth. Genotypes selected for high (H) and low (L) $\mathrm{CO}_{2}$ exchange rate (CER) and yield.

\begin{tabular}{|c|c|c|c|c|c|c|c|c|c|}
\hline \multirow[b]{2}{*}{ Genotype } & \multicolumn{3}{|c|}{ Leaf area } & \multicolumn{2}{|c|}{ Harvest index $\dagger$} & \multicolumn{3}{|c|}{ Tiller } & \multirow[b]{2}{*}{ Yield/tillerf } \\
\hline & Initial & Final & Change & Initial & Final & Initial & Final & Change & \\
\hline (CER-yield) & ב & $\mathrm{dm}^{2}$ & 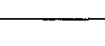 & - & $\ldots$ & + & - No. & 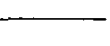 & $\mathrm{mg}$ \\
\hline $\begin{array}{l}\text { H-H } \\
\text { H-L } \\
\text { L-H } \\
\text { L-L } \\
\quad \text { L.S.D. (0.05) }\end{array}$ & $\begin{array}{l}1.64 \\
2.02 \\
2.08 \\
1.86 \\
0.33\end{array}$ & $\begin{array}{l}5.69 \\
4.54 \\
5.76 \\
3.85 \\
0.83\end{array}$ & $\begin{array}{l}4.05 \\
2.53 \\
3.68 \\
1.99 \\
1.04\end{array}$ & $\begin{array}{l}0.08 \\
0.20 \\
0.09 \\
0.17 \\
0.03\end{array}$ & $\begin{array}{l}0.24 \\
0.32 \\
0.28 \\
0.34 \\
0.04\end{array}$ & $\begin{array}{r}42 \\
31 \\
46 \\
37 \\
3\end{array}$ & $\begin{array}{r}75 \\
64 \\
66 \\
54 \\
7\end{array}$ & $\begin{array}{r}33 \\
33 \\
20 \\
17 \\
9\end{array}$ & $\begin{array}{r}49 \\
39 \\
58 \\
45 \\
8\end{array}$ \\
\hline
\end{tabular}

$\uparrow$ Each mean is based on calculation of harvest index for eight experimental units.

¥ Yield data from final leaf weight presented in Table 2.

root weight)]. The high yielding genotypes had a less favorable ratio at the initial harvest, and the L-L genotypes had a more favorable ratio at the final harvest (Table 3). These data suggest that the genotypes were using different mechanisms to develop forage yield. The high yielding genotypes produced less leaf mass per unit of stem base and root mass; however, their total production of leaf tissue was greater than that of the low yielding genotypes.

Number of tillers was significantly greater for the high yielding genotypes at the initial harvest (Table 3); however, at the final harvest, the $\mathrm{H}-\mathrm{H}$ genotype had significantly more tillers, and the L-L genotype had significantly fewer tillers, with the H-L and L-H genotypes having an intermediate number. Increase in tiller number between the two harvests was greater for the high than for the low-CER genotypes. Yield per tiller was significantly higher for the L-H genotype, which was also the genotype that produced the greatest amount of dry matter. In this study, plants were grown in plastic pots with little intertiller competition and with ample water and mineral nutrition throughout the experiment. The translation of these data to a field situation might be questionable if a maximum tiller density had been established. Under a relatively high tiller density, the yield per tiller relationship among genotypes might change considerably (Simons et al., 1973).

The $\overline{\mathrm{RGR}}$ of the four genotypes were very similar (Table 4), suggesting that, if initial plant sizes were equal, the absolute growth rates would be similar. Mean leaf area ratio $\overline{(\mathrm{LAR})}$, which measures leaf area relative to total plant weight (Table 4), showed patterns similar to the harvest index (Table 3) for the four genotypes. This occurred because SLW was similar for all genotypes.

Mean net assimilation rate $\overline{(\overline{N A R})}$ indicated that high yielding genotypes ( $\mathrm{H}-\mathrm{H}$ and $\mathrm{L}-\mathrm{H}$ ) tended to have greater $(P<0.07)$ dry matter production per unit leaf area than did low yielding genotypes (H-L and L-L) (Table 4), although differences were not significant at $P<0.05$. This was in contrast with the CER categories for which the genotypes were selected. A

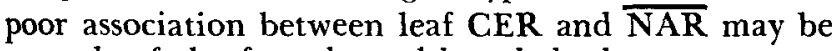
a result of the fact that, although both are measures of photosynthetic efficiency per unit leaf area, they are determined from opposite ends of the growth spectrum. The CER measures $\mathrm{CO}_{2}$ incorporation without regard for utilization efficiency by the plant. On the other hand, $\overline{\mathrm{NAR}}$ measures dry matter increase per se. Many things may influence efficiency of pho-
Table 4. $\mathrm{CO}_{2}$ exchange rate (CER) and growth analysis data for four tall fescue genotypes.

\begin{tabular}{cccccc}
\hline Genotype & CER & $\overline{\mathrm{RGR}}$ & $\overline{\mathrm{LAR}}$ & $\overline{\overline{\mathrm{RLaRG}}}$ & $\overline{\mathrm{NAR}}$ \\
\hline (CER-yield) & $\begin{array}{c}\mathrm{mgCO} \\
\mathrm{dm}^{-2} \mathrm{hour}^{-1}\end{array}$ & $\begin{array}{c}\mathrm{gg}^{-1} \\
\mathrm{day}^{-1}\end{array}$ & $\mathrm{dm}^{2} / \mathrm{g}$ & $\begin{array}{c}\mathrm{dm}^{2} \mathrm{dm}^{-2} \\
\mathrm{day}^{-1}\end{array}$ & $\begin{array}{c}\mathrm{g} \mathrm{dm}^{-2} \\
\mathrm{day}^{-1}\end{array}$ \\
H-H & 14.2 & 0.024 & 0.208 & 0.078 & 0.112 \\
H-L & 15.0 & 0.028 & 0.354 & 0.048 & 0.080 \\
L-H & 10.6 & 0.022 & 0.248 & 0.062 & 0.100 \\
L-L & 9.6 & 0.020 & 0.341 & 0.042 & 0.066 \\
L.S.D. (0.05) & 1.8 & $\mathrm{NS}$ & 0.039 & 0.019 & $\mathrm{NS}$ \\
\hline
\end{tabular}

tosynthetic utilization between genotypes, such as growth and maintenance respiration.

Mean relative leaf area growth rate $\overline{(\mathbf{R L a G R})}$ (Table 4) indicated that leaf area increase per unit of initial leaf area was greater for the H-H genotype than for the L-L genotype. Also, the high-CER genotype within each yield category tended to have a great-

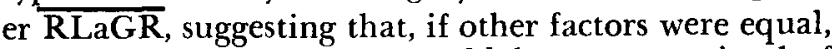
the high-CER genotypes would have a superior leaf growth rate and, therefore, greater yield.

Results of the growth analysis study further suggested that several factors may be working together to enable the high yielding genotype to produce greater amounts of harvestable dry matter regardless of CER. High yielding genotypes had greater leaf growth rates (Wilhelm and Nelson, 1978b), which not only gave these genotypes a yield advantage because leaves contributed a greater portion of the plant's total harvested biomass, but they also had the advantage of increasing photosynthetic area more rapidly (Simons et al., 1973). This more rapid increase in photosynthetic tissue would also maintain a relatively greater amount of young leaf area on the plant that is capable of higher CER than older tissue (Wilhelm and Nelson, 1978b).

The close association between yield expressed by the genotypes and rate of increase in whole-plant weight and increase in carbohydrates suggested that the amount of "initial capital" (Watson, 1952) plays an important role in determining yield potential of tall fescue. With a larger stem base and root mass and more carbohydrate reserve to draw on, initial leaf production of the high yielding genotype during regrowth was greater. Booysen and Nelson (1975) studied the effect of high and low concentrations of WSC on regrowth of tall fescue and found high WSC concentrations allowed greater leaf area increases, greater total plant weight increases, and greater final WSC content than did treatment with low WSC concentrations. This, added to the greater leaf growth rate and 


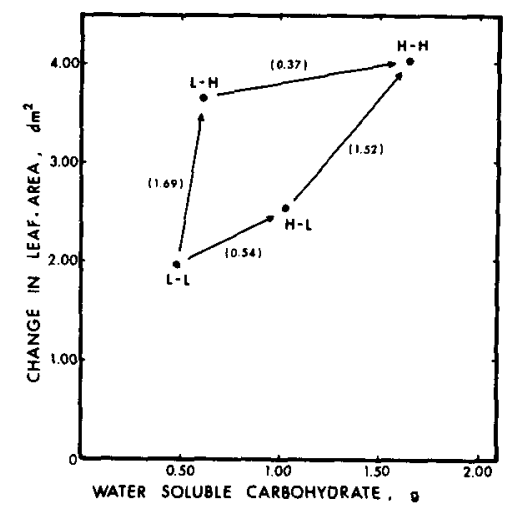

Fig. 1. Effect of selection for $\mathrm{CO}_{2}$ exchange rate (CER) and yield on water-soluble carbohydrates (WSC) and leaf development in tall fescue. Genotypes were selected for high CER-high yield (H-H), high CER-low yield (H-L), low CER-high yield (L-H), and low CER-low yield (L-L). Numbers in parentheses indicate the change in leaf area between the two adjacent genotypes.

more favorable dry matter distribution $\overline{(\mathrm{RLaGR})}$ expressed by the high yielding genotypes during early regrowth stages, resulted in a compounding effect, which probably accounted for the greater yield.

The question remains as to how high yielding genotypes establish their larger plant size. Data presented here may give some indication as to how this occurs. Rapid leaf growth of high yielding genotypes predisposes them to achieving any particular leaf area index (LAI) sooner than the low-yielding genotypes. The more complete interception and utilization of solar energy by the canopy would result in a greater amount of photosynthate available for the plant regardless of CER (Simons et al., 1973). As this occurs, the high yielding genotypes may be able to divert more assimilated $\mathrm{CO}_{2}$ to growth of roots and storage organs than the low yielding genotypes, which are still producing leaf tissue. Therefore, the high yielding genotypes are able to develop a larger plant size.

The four genotypes apparently use different mechanisms to produce their levels of yield. The $\mathrm{H}-\mathrm{H}$ genotype combined rapid leaf growth with high CER to develop a large stem base and root system as well as high carbohydrate reserves to allow rapid regrowth after harvest. The L-H genotype with its lower CER relied mainly on rapid leaf growth, rapid development of critical L.AI, and a relatively large amount of young leaf tissue to produce a large root and stem base mass, but with lower WSC concentration for use in regrowth. The H-L genotype, although having a high CER, could not capitalize on it because of its slow leaf growth. The L-L genotype had a low CER, but did not have the high leaf growth with which to compensate and, therefore, was capable only of low yield.

In Fig. 1, change in leaf area between the initial and final harvest was plotted against mass of WSC (tissue weight $\times$ WSC content summed over all plant parts) that was available at the first harvest. A general, positive relationship existed between the two variables with selection for both high yield and high CER leading to higher WSC and leaf area production. However, when comparing genotype L-L to H-L, and $\mathrm{L}-\mathrm{H}$ to $\mathrm{H}-\mathrm{H}$, an increase in leaf area production between harvests of 0.54 and $0.37 \mathrm{dm}^{2}$, respectively, accompanied the selection for high photosynthesis. In contrast, a change in leaf area production approximately three times that previously stated, 1.69 and 1.52 $\mathrm{dm}^{2}$, occurred when $\mathrm{L}-\mathrm{L}$ and $\mathrm{H}-\mathrm{L}$ genotypes were compared to the $\mathrm{L}-\mathrm{H}$ and $\mathrm{H}-\mathrm{H}$ genotypes, respectively. In both cases the selection for high yield had a much greater impact on leaf growth than did selection for high CER. These data support earlier findings (Nelson and Asay, 1974; Nelson et al., 1975) that selection for CER alone in forage grasses such as tall fescue will not produce high yielding genotypes unless concomitant pressure is placed on yield characters.

\section{REFERENCES}

1. Booysen, P., and C. J. Nelson. 1975. Leaf area and carbohydrate reserves in regrowth of tall fescue. Crop Sci. 15:262. 266.

2. Epstein, E. 1972. Mineral nutrition of plants: Principles and perspectives. John Wiley and Sons, Inc., New York.

3. Hanson, W. D. 1971. Selection for differential productivity among juvenile maize plants: Associated net photosynthetic rate and leaf area change. Crop Sci. 11:334-339.

4. Hoveland, C. S., H. W. Foutch, and G. A. Buchanan. 1974. Response of Phalaris genotypes and other cool-season grasses to temperature. Agron. J. 66:686-690.

5. Nelson, C. J., and K. H. Asay. 1974, Photosynthetic efficiency as a selection criterion in breeding forage grasses. In Plant introduction, breeding and seed production section. XII Int. Grassland Cong. Proc. (Moscow, USSR). p. 914-920.

6. - - --- , and G. L. Horst. 1975. Relationship of leaf photosynthesis to forage yield of tall fescue. Crop Sci. 15:476-478.

7. - - - - - - measurement of photosynthesis in a forage grass breeding program. Crop Sci. 14:26-28.

8. Radford, P. J. 1967. Growth analysis formulae - their use and abuse. Crop Sci. 7:171-175.

9. Simons, R. G., Alison Davies, and A. Troughton. 1973. The effect of spacing on the growth of two genotypes of perennial ryegrass. J. Agric. Sci. (Cambridge) 80:495-502.

10. Smith, Dale. 1969. Removing and analyzing total nonstructural carbohydrates from plant tissue. Wis. Agric. Exp. Stn. Res. Rep. 41 .

11. Treharne, K. J., and C. F. Eagles. 1970. Effect of temperature on photosynthetic activity of climatic races of Dactylis glomerata L. Photosynthetica 4:107-117.

12. Watson, D. J. 1952. The physiological basis of variation in yield. Adv. Agron. 4:101-145.

13. Wilhelm, W. W., and C. J. Nelson. 1978a. Irradiance response of tall fescue genoytpes with contrasting levels of photosynthesis and yield. Crop Sci. 18:405-408.

14. ___- and _-_ 1978b. Leaf growth, leaf aging, and photosynthetic rates of tall fescue genotypes. Crop Sci. 18: 769-772

15. Yoshida, S. 1972. Physiological aspects of grain yield. Annu. Rev. Plant Physiol. 23:437-464. 